\title{
Influence of exchange rate on cross-border shopping of Bruneians in Malaysia
}

\author{
SAIFUL ISLAM ${ }^{\mathrm{a},{ }^{*}}$, NURUL FAIZAH SALLEH ${ }^{a}$, SITI NOORAINI SABLI ${ }^{a}$ \\ ${ }^{a}$ UTB School of Business, Universiti Teknologi Brunei, Brunei
}

\begin{abstract}
A R T I C L E I N F O
A B S T R A C T

Received: 4 Mar, 2018

Revised: 15 May, 2018

Accepted: 1 Oct, 2018

Available online

JEL classification:

D12, F31, F42

Keywords:

Cross-border shopping;

Exchange rate;

One of the effects of exchange rate fluctuations is cross-border shopping by consumers. This paper provides an empirical analysis of the effects of Malaysian ringgit depreciation on cross-border shopping of Bruneians. This has been done by using daily data from 1 January 2014 to 31 December 2016 (total 1,096 observations) on traffic flows to Miri, a border town of Eastern Malaysia. We find that a 1 percent increase in the depreciation of Malaysian ringgit per Brunei dollar increases the number of Bruneian shoppers to Miri by 2.10 percent. We also estimated that the average spending per person per trip to Miri is $\mathrm{B} \$ 155$ and the total spending of Bruneian shoppers in Miri is $\$ 175$ million a year. This total spending is 1.11 percent of gross domestic product of Brunei in 2016. The result from this study would be helpful in designing policies for cross-border shopping of Bruneians. This is because the number of visits and the total expenditure amount of Bruneians in Miri are related to high outflow of money which results in a loss to the local economy - which may deteriorate local business.
\end{abstract}

Bruneian shoppers;

Miri Malaysia.

\footnotetext{
* Corresponding author.

Email: saiful.islam@utb.edu.bn (Saiful Islam).

Please cite this article as: Islam, S., Salleh, N. F., \& Sabli, S. N. (2019). Influence of exchange rate on cross-border shopping of Bruneians in Malaysia. Journal of Asian Business and Economic Studies, 26(S01), 74-92.
} 


\section{Introduction}

Cross-border shopping activities are rising much faster than before. It has been of interest due to its significant impact on the retail sales of shops on both sides of the border (Piron, 2002; Lau et al., 2005). It could be a serious economic concern for a city with huge drainage of retail sales to its competitive neighbor across the border. For instance, every month there are about 900,000 day trippers from Singapore crossing to Johor Baru, the border town of Malaysia, for shopping, recreation, and food (Piron, 2002) and this huge drainage of retail sales had become a serious concern of the Singaporean government (Piron, 2002). Crossborder shopping may, therefore, have profound implications for revenue of a country (Espland et al., 2005; Lau et al., 2005). Purchases made by foreigners represent an export of goods and services in the destination country, leading to an improvement in the balance of payment and growth.

Many motivating factors are alluded to as drivers of cross-border shopping. Major reasons for cross-border shopping include the price benefits expected from visitors from a higher gross domestic product (GDP) per capita host country (Piron, 2002; European Commission, 2004; Subramanium et al., 2013); and the existence of a favorable exchange rate between currencies and higher taxes in the host country (Neilson, 2002). Other non-price factors are important drivers of cross-border shopping, including the original or exclusive nature of the item; the extent of the choice and range available; the quality or the authenticity; the pleasure of shopping (European Commission, 2004), and accessibility (Tak \& Wan, 2008).

Though cross-border shopping is common in various parts of the world, most academic attention focuses upon its development in North America and Europe (Gelbman \& Timothy, 2010; Subramanium et al., 2013; Bello, 2017). The present study, therefore, contributes to extant literature by considering cross-border shopping from a South East perspective, following an examination of the behavior of shoppers from a high income country (Brunei) to a middle-income country (Malaysia). In 2014, Brunei and Malaysia recorded gross domestic product per capita of US $\$ 41,631$ and US\$11,009, respectively (IMF, 2018).

Exchange rate is one of the most significant factors for cross-border shoppers (Bello, 2017). In many parts of the world, consumers routinely cross the border to make their purchases. Nominal exchange rate fluctuations are known to be related to persistent price differences for similar goods across countries (Engel \& Rogers, 1994), which affect the number of cross-border shoppers (Chandra et al., 2014).

In this paper, we study the effects of nominal exchange fluctuations on cross-border shopping of Bruneians in Miri, a border town of the Sarawak state of Malaysia. The statistics report that in 2016, a total of 1,129,050 Bruneians visited Miri (an upsurge of 22 percent from 2015). This may be because the value of the Malaysian currency (the ringgit) is lower compared with the Brunei currency (the dollar). Thus, Bruneian residents cross the border 
to buy goods and services at cheaper prices. The location of Miri and Brunei is shown in Figure 1.

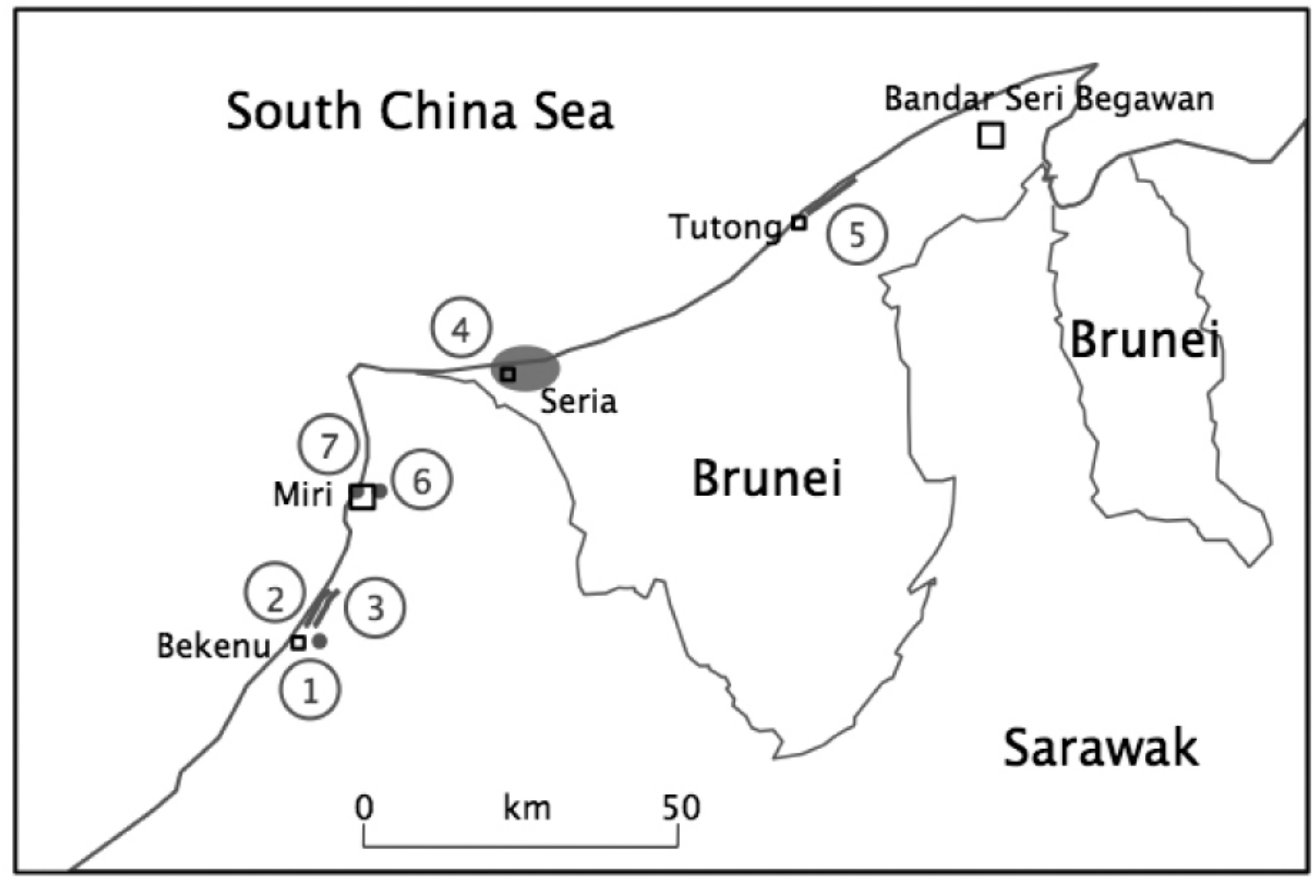

Figure 1. Location of Brunei and East Malaysian Border Town of Miri ${ }^{1}$

The motivation for undertaking this study comes from the fact that exchange rate effects on cross-border shopping of Bruneians have never been formally documented in economic literature. From August 2014 to March 2017, the amount of Malaysian ringgit needed to purchase one Brunei dollar increased from 2.543 to 3.159 (AMBD, 2017). As a result of this depreciation, Malaysian products became much cheaper for Bruneians to buy and this might have made cross-border shopping much more attractive for Bruneians. During the period 2008-2013, the Malaysian-Brunei currency exchange rates were almost stable around 2.40 ringgit per Brunei dollar, then began to depreciate in August 2014 (Figure 2).

\footnotetext{
${ }^{1}$ Source: http://www.ctoz.nl/c/ctz/images/vol78/nr03/7803a03fig0.jpg
} 


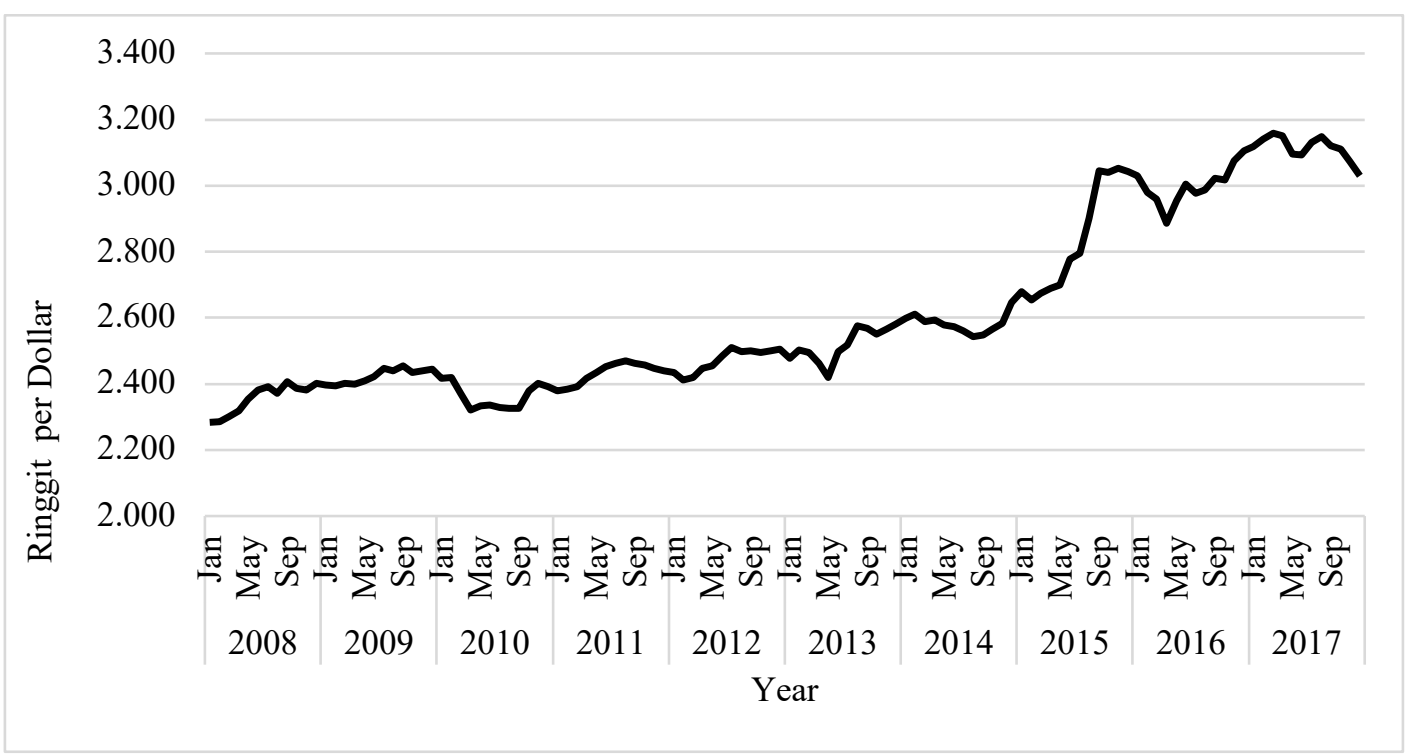

Figure 2. Malaysian Ringgit-Brunei Dollar Exchange Rate, 2008-2017 (Monthly Average)2

Note: This Figure 2 shows the number of Malaysian ringgit (MYR) needed to buy 1 Brunei dollar (BND). AMBD provides data for number of Brunei dollars per 100 Malaysian ringgit. From these exchange rates, we have calculated the number of MYR per BND, as shown in this figure.

The number of visits to Miri for shopping may have a profound implication for revenue of Brunei as high outflows of expenditure are believed to have contributed to the high amount of leakages from Brunei. This has been a major policy concern as there is a possibility that Bruneians are overspending in the cross-border towns of East Malaysia (Rizzo et al., 2014).

Based on the above background, this article has two main objectives. The first objective is to analyze the response of cross-border shoppers to the nominal exchange rate movements. It is believed that the cheap prices and a weak currency in the neighboring areas encourage Bruneians to cross the border to shop. The second objective is to measure the out flow of money from Brunei due to cross-border shopping in Miri.

Brunei is the smallest of all the Southeast Asian economies with its population size. The current population of the country is about 423 thousand, 78 percent of which live in urban areas. Brunei covers 5,765 square kilometers of the island of Borneo. It is bounded by the South China Sea in the north and all other sides are bounded by the Malaysian State of Sarawak which divides Brunei into two parts i.e. the eastern part which is the Temburong district and the western part which consists of the Brunei-Muara, Tutong and Belait districts. The country acceded to full independence in January 1984, following nearly 80 years as a British protectorate.

Brunei is a high-income country with vast petroleum wealth. Oil and gas resources have generated high per capita income (US\$40,979 in 2014), although the economy has contracted

\footnotetext{
2 Source: Authoriti Monetari Brunei Darussalam, AMBD Statistical Bulletin Q4 2017.
} 
in recent years as a result of falling oil and gas prices, which account for more than 90 percent of export revenue (Oxford Business Group, 2016). Brunei is the fifth largest crude oil producer in Southeast Asia, after Indonesia, Malaysia, Vietnam and Thailand, and is the eleventh largest exporter of liquefied natural gas (LNG) in the world. Japan and the Republic of Korea are the major customers for natural gas and crude oil exports of Brunei (BP, 2017). International trade plays a large part in the Brunei economy, through the export of oil and gas and the import of food and manufactures.

For the purpose of this study we have chosen Miri because of the following reasons: First, the activities enjoyed by the Bruneians are more in Miri than in any other border towns of East Malaysia. These activities include shopping, dining, sightseeing, amusement/theme parks, concert, plays, leisure and recreation (Rizzo \& Hau, 2015). Second, even though data shows that the Kuala Lurah Control Post has the highest number of travelers crossing the border, this data cannot be used because the post is the entry to Limbang town from where people commute to work to Temburong, a Bruneian district. Some also go to Kota Kinabalu in East Malaysia from Limbang so the number of people that cross this border only for shopping, as is the focus of this paper, is not exact.

\section{Literature review}

There are two important aspects related to cross-border shopping: shopping motivation and shopping behavior (Solomon, 2012). Shopping motivation refers to the factors that influence the frequency of cross-border shoppers. Many motivating factors are known as drivers of cross-border shopping which include exchange rate, varieties of products and services offered, and the amount of places to visit. Shopping behavior is the manner in which one acts or behaves. This includes what the shoppers buy, how much they spend on each trip, where they go to spend or which place they like to go.

Exchange rate is known to be a major factor of cross border shopping. Bello (2017) cites evidence that studies on the response of cross-border shopping to the exchange rate movements are still very few and focus mainly on the Canada-US border. The first evidence is provided by Chandra et al. (2014), who uses micro-data on vehicle counts for provinces along the Canada-US border and shows that a 10 percent appreciation of the home currency increases the propensity to cross the border by 8 percent to 26 percent.

Bello (2017) also studies the effects of exchange rate fluctuations on cross-border travel by both workers and consumers on the Swiss-Italian border. He defines cross-border travel as crossing the border to go to work and to do shopping. He uses hourly data on traffic flows in Ticino (the southernmost canton of Switzerland) over the 2005-2015 period. He analyses the effects of the Swiss franc appreciation on cross border travel by both Italian workers and Swiss consumers and on sales of Italian retailers. He found that a 10 percent appreciation of the Swiss franc increases the number of cars along the border by 1.5-3 percent more than in 
the rest of the canton. He also found that a stronger Swiss franc positively affects the sales of supermarkets in Italian provinces bordering Switzerland.

Despite the increasing numbers of cross-border shoppers from Brunei, we have found only four studies on the Brunei context. Lee (2018) focuses on factors influencing the frequency of cross border tourism and investigates the cross-border shopping behavior of Bruneian visitors between Brunei and Eastern Malaysia. She finds many motivating factors as drivers of cross-border tourism which include price benefit, exchange rate as well as nonprice factors such as extent of choice availability. She did not estimate the effects of exchange rate fluctuations on cross-border shopping of Bruneians.

Rizzo et al. (2014) have done a study on shopping behavior of Bruneian cross-borders shoppers. They focus on cross-border expenditure of Bruneians in Miri. Their survey findings show that most Bruneians go to Miri not only for shopping, but for other activities, such as entertainment and visiting friends and family. They also find that the main reasons for shopping in Miri is the wider variety of choices available and lower prices of goods and services; the quality of goods and services does not seem to be an important factor of attraction to Miri. Their survey findings also show that Bruneians spend a total of B $\$ 205.16$ per group per trip, which corresponds to a total of $\mathrm{B} \$ 61.3$ million a year. This estimated amount represents 1.4 percent of household final consumption expenditure in 2013. As it is quite a low figure comparatively, they argue that it is not a major policy concern by itself.

Similar findings are also obtained by Rizzo and Hau (2015). Their survey responses show that the most common purpose for the cross border visits amongst Bruneians is shopping (70 percent of the sample). This is particularly true for the respondents going to Limbang and Miri. Holiday and leisure is the main purpose of visit for 42 percent respondents. Except for Bruneians going to Limbang, holiday and leisure is an important motive for the majority of the trips. The average expenditure is significantly different across destinations: the minimum is less than $\mathrm{B} \$ 250$ in Limbang, whereas the maximum is more than $\mathrm{B} \$ 3,000$ in Singapore.

Subramaniam et al. (2013) investigate the cross-border shopping behavior of Bruneian visitors in Limbang, Malaysia. Based on a survey of 35 respondents, they find that most Bruneian cross-border shoppers are day trippers and represent the lower income group. They also find that the purchasing behavior of day trippers differs from that of short-term visitors; and the key reasons for Bruneians shopping in Limbang are the favorable exchange rate, the availability of various/reliable services, and the retail atmosphere, which are compensated for by the safe and easy access, as well as the low transport costs associated with the travel. The study however, did not estimate the total expenditure of Bruneians in Limbang given the small sample size. The study also fails to do any econometric exercises for the effect of exchange rate on the cross-border shopping of Bruneians.

The above studies on the cross-border shopping of Bruneians however, did not estimate the response of cross-border shopping to exchange rate. This is a sharp research gap. To fill in the existing gap in the literature, this study attempts to provide initial evidence of the 
responsiveness of cross-border shopping to the exchange rate, using Brunei as a case study. In addition, the current study will also look at the levels of spending amongst Bruneian visitors in Miri on the basis of a survey of sample respondents. It is hoped that this study will provide empirically based insight into the issue and act as a baseline for more studies.

\section{Methodology}

The conceptual framework for analyzing cross-border shopping of Bruneians includes five key factors (Figure 3). The factors are exchange rate, payday, bonus, holiday and sales promotion. We believe that these factors motivate and encourage Bruneians to go crossborder to Miri.

Exchange rate influences the motives of travel as the weaker Malaysian currency means that goods and services would be much cheaper than in Brunei (Lee, 2018). The strength of Brunei dollar against the weaker Malaysian ringgit makes it more beneficial for Bruneians to spend on goods and services in the neighboring country.

Payday and bonus are related to income level. People from higher income categories are likely to go cross-border and spend more in the neighboring country (Rizzo et al., 2014). Just after payday and bonus, Bruneians get more purchasing power to do some shopping in Miri.

Cross-border shopping is more likely to occur during school holidays and public holidays (Cheong \& Rahman, 2015). They do so primarily for retail shopping and leisure \& recreation.

Sales promotion season in Miri is also expected to attract more Bruneian shoppers to bargain goods at discounted prices (Kuncharin \& Mohamed, 2014). Thus, sales effect is assumed to be one of the reasons for Bruneians to go cross-border shopping to Miri.

However, slowest traffic was recorded in November 2015 when Malaysian police set up roadblocks to impose fines on traffic offenders from Brunei. There was also a dip in Bruneians making trips across the border when Malaysian government first introduced GST (goods and services tax, at a rate of 6 percent) in April 2015. In 2016, official data recorded nearly 2.5 million departures through the Sungai Tujoh, Kuala Lurah and Serasa Ferry Terminal immigration posts. 


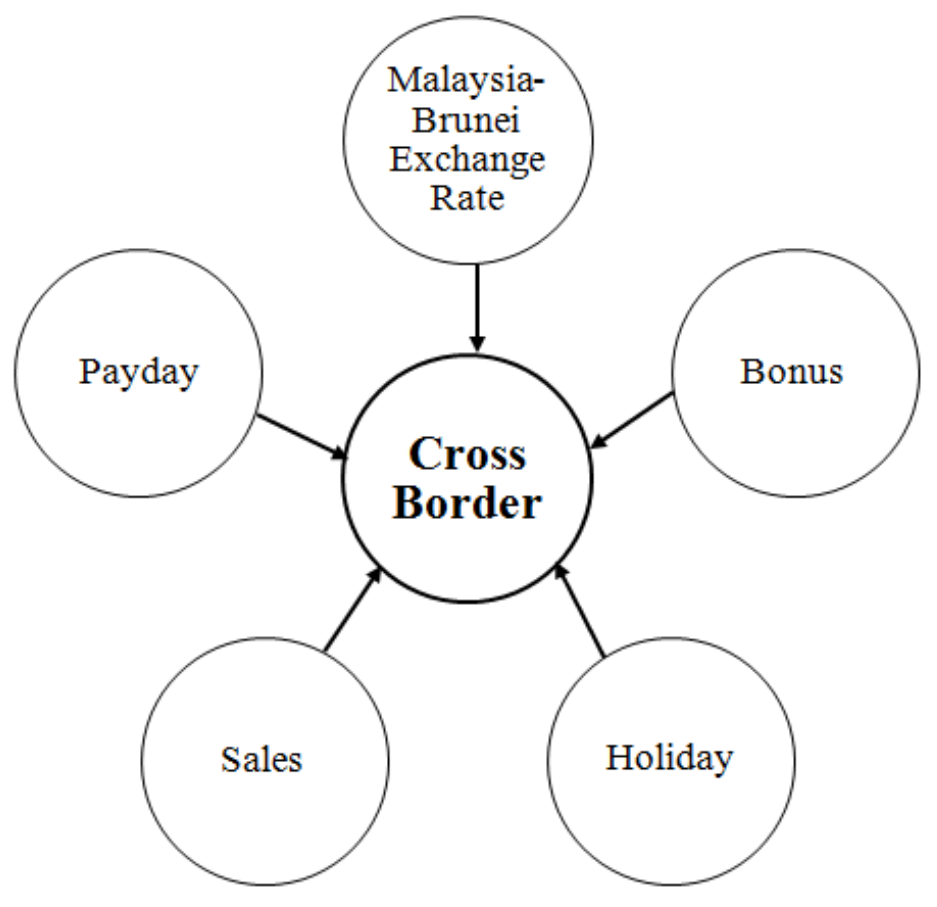

Figure 3. Conceptual Framework

Based on this conceptual framework in Figure 3, we specify our regression model of Bruneian shoppers to exchange rate, payday, holiday, bonus and sales. The dependent variable is the log Bruneian shoppers denoted by the number of visitors to Miri. The regression model consists of five independent variables; log exchange rate (Malaysian ringgit per Brunei dollar), payday in Brunei, holiday \& bonus in Brunei and sales promotion in Miri.

The econometric model used for estimation is specified as follows:

In Bruneian Shoppers $=\alpha_{0}+\beta_{1}$ ln Exchange Rate $+\beta_{2}$ Payday $+\beta_{3}$ Sales $+\beta_{4}$ Holiday $+\beta_{5}$ Bonus $+u_{i}$

where: In Bruneian Shoppers is the natural logarithm of the number of Brunei shoppers going to Miri from January 1, 2014 to December 31, 2016;

In Exchange Rate is the natural logarithm of the exchange rate between Malaysian ringgit (MYR) per Brunei dollar (BND) over the period January 1, 2014 to December 31, 2016;

Payday is a dummy variable with 1 representing the first 15 days of payday period for Brunei and zero representing the last 15 days of payday period;

Sales is a dummy variable with 1 representing during sales promotion period in Miri and zero representing when there is no sales promotion;

Holiday is a dummy variable with 1 representing public and school holidays and weekend in Brunei and zero representing working days; 
Bonus is a dummy variable with 1 representing the first 20 days of bonus period for Brunei and zero representing the last 20 days of bonus period;

$u_{i}$ is the error term initially assume to have a mean of zero and constant variance.

Data on the number of cross-border shoppers to Miri are obtained from Sungai Tujoh Immigration Control Post in Kuala Belait. Data on daily exchange rates between Brunei and Malaysian currencies are obtained from "Brunei dollar (BND) to Malaysia ringgit (MYR) exchange rate history"3

In total there are 1,096 observations where 1 observation represents 1 day. The observations are for 3 years starting from January 1, 2014 to December 31, 2016. During this period, the Malaysian ringgit fluctuated more than any other period as seen in Figure 2. Ringgit exchange rates show the most pronounced increases in this period. The ringgit started to depreciate in August 2014 and continued to do so in 2016.

The log-log model is used to provide a better interpretation as the coefficients in this represents the elasticity of log Bruneian shoppers with respect to log exchange rate.

Average number of shoppers per day crossing Sungai Tujoh control post and RinggitDollar exchange rates from January 2014 to December 2016 are shown in Figure 4.

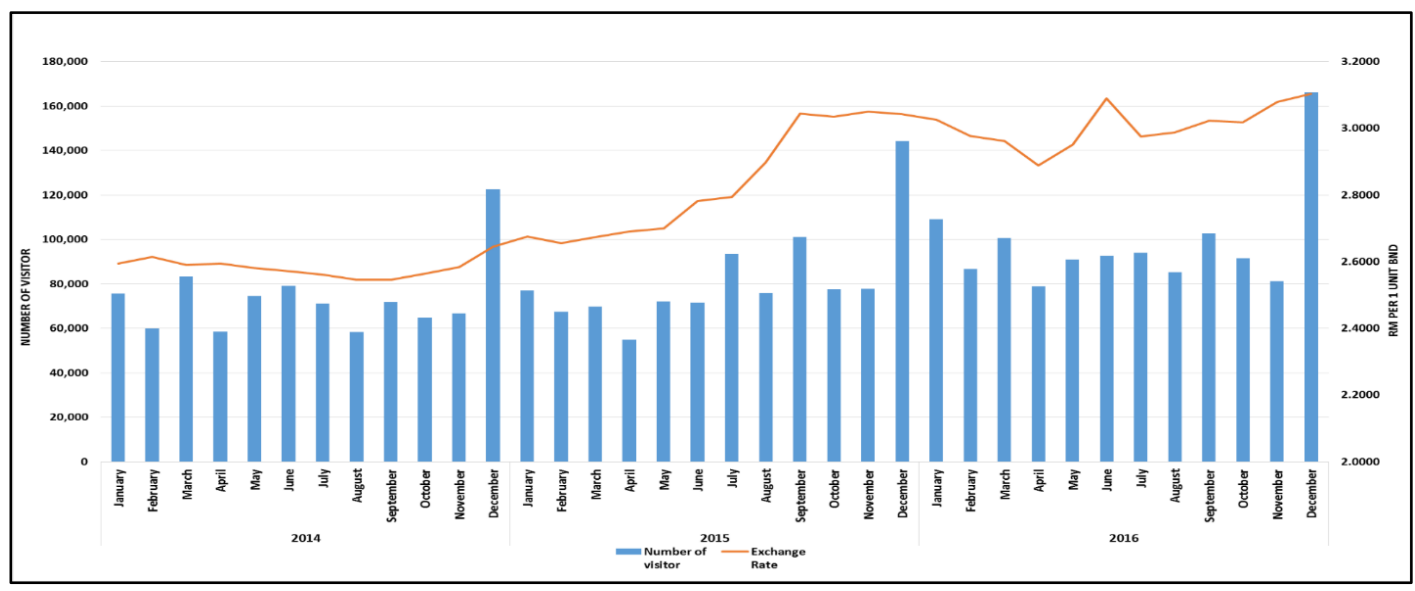

Figure 4. Number of Bruneian Visitors to Miri and Malaysia-Brunei Nominal Exchange Rate, January 2014-December 2016

This figure shows that the number of Bruneian visitor increases with the depreciation of Malaysian Ringgit against Brunei Dollar. We included the statistics from the year 2014 to 2016 because there was a drastic fluctuation of Malaysian Ringgit in mid-2015 in comparison from 2014. Unusual trend was recorded every year on December and this could be due to payday in Brunei, sales promotion in Miri, holiday in Brunei, and bonus in Brunei which occurred at the same time. Regression analysis must be conducted to test whether the

\footnotetext{
${ }^{3}$ https://www.exchangerates.org.uk/BND-MYR-exchange-rate-history.html
} 
increase in the number of Bruneian visitor is due to the depreciation of Malaysian Ringgit against Brunei Dollar, or due to the variables payday, holiday, bonus an sales.

\section{Results of regression of cross-border shopping}

Table 1 gives the regression results of cross-border shoppers to exchange rate, pay day, sales, holiday and bonus. The regression model is estimated by STATA, using daily data on cross-border shoppers and exchange rates for the period January 1, 2014 to December 31, 2016. The other independent variables (payday, bonus, holiday, and sales) are used as dummy variables.

\section{Table 1}

Regression of Log Brunei Shoppers to Log Exchange Rate, Payday, Holiday, Bonus and Sales

\begin{tabular}{lcccccc}
\hline In Brunei Shoppers & Coef. & Std. Err & $\mathrm{t}$ & $\mathrm{P}>|\mathrm{t}|$ & \multicolumn{2}{c}{ [95\% Conf. Interval] } \\
\hline ln Exchange Rate & 2.098 & 0.170 & 12.32 & 0.000 & 1.763 & 2.432 \\
Payday & 0.119 & 0.024 & 4.93 & 0.000 & 0.072 & 0.166 \\
Sales & 0.008 & 0.025 & 0.34 & 0.735 & -0.041 & 0.058 \\
Holiday & 0.709 & 0.024 & 28.85 & 0.000 & 0.661 & 0.758 \\
Bonus & 0.226 & 0.053 & 4.29 & 0.000 & 0.123 & 0.330 \\
_cons & 5.238 & 0.175 & 29.87 & 0.000 & 4.893 & 5.581 \\
\hline
\end{tabular}

The AOV table

\begin{tabular}{lccc}
\hline Source & SS & df & MS \\
\hline Model & 174.710 & 5 & 34.942 \\
Residual & 170.955 & 1,090 & 0.157 \\
Total & 345.665 & 1,095 & 0.316 \\
\hline
\end{tabular}

Number of obs $=1,096$

$\mathrm{F}(5,1090)=222.79$

Prob $>\mathrm{F}=0.0000$

R-squared $=0.505$

Adj R-squared $=0.503$

Root MSE $=0.396$

Note: $|\mathrm{t}|$ means the absolute $\mathrm{t}$ value because $\mathrm{t}$ can be positive or negative. $\mathrm{AOV}=$ Analysis of Variance. 
From Table 1, all the independent variables, except sales, are significant even at a 1 percent significance level, $t$-values for holiday is the highest (28.85) followed by exchange rate (12.32), payday (4.93), and bonus (4.29).

We can also see that the independent variables of log exchange rate, payday, holiday and bonus are significant because their $\mathrm{p}$-values are 0.000 . However, the p-value for sales is greater than the common alpha level of 0.05 which indicates that it is not significant. Therefore, we should consider removing sales from the regression model. Accordingly we have re-estimated the model excluding sales variable, but the results are similar to those including sales variables (as in Table 1).

The F-test shows that all variables included in the model are collectively and statistically significant with a p-value of 0.000 . The R-squared value of 0.5054 confirms this. This means that 50.54 percent of the variation in log Bruneian shoppers is explained by the variation in the five explanatory variables - exchange rate, payday, sales, holiday, and bonus.

The econometric model with the value of the $\operatorname{coefficients}(\beta)$ is shown below:

Ln Bruneian Shoppers $=5.23+2.10$ ln Exchange Rate +11.9 Payday +0.8 Sales +70.9 Holiday

$$
+22.6 \text { Bonus }+u_{i}
$$

From Table 1, the coefficient value for log exchange rate is 2.10 which indicates that a 1 percent increase in the depreciation of Malaysian Ringgit per Brunei Dollar leads to a 2.10 percent increase in the number of Bruneian shoppers to Miri. The result shows that exchange rate changes are statistically significant in influencing the number of Bruneian shoppers to Miri. When the Malaysian Ringgit depreciates it triggers Bruneians to go to Miri and increase their spending pattern. This further suggests that Bruneians are price sensitive in their demand for goods. When the exchange rate changes, they prefer travelling to Miri for shopping due to the price decrease gained through the exchange rate.

The coefficient of payday effect is 11.9 percent. This means that the number of people travelling to Miri is 11.9 percent higher in the first 15 days after payday then in the remaining days of the month. This result is also statistically significant with a p-value of 0.0000 . As expected Bruneian would flock to Miri after receiving their salary because it would generally increase the purchasing power (with respect to availability of funds) of Bruneians to spend in Miri.

The coefficient of sales promotion in Miri is 0.8 percent, which shows the mean difference between when there is sales promotion in Miri and when there are no sales. The positive sign means that the average visit per day is more during sales promotion period in Miri than when there are no sales by 0.8 percent. However, the result shows that sales promotion in Miri is not statistically significant in influencing the number of Bruneian shoppers to Miri as people are not aware with the sales promotion in Miri. The increase in the number of shoppers by 0.8 percent might not explain the exact sales promotion effect but the figure might represent those people who went there coincidentally during sales.

The coefficient of holiday effect is 70.9 percent, which shows the mean difference between during holiday and working days. The positive sign means that the average visit 
per day is more during holiday than working days by 70.9 percent. This shows that the holiday period in Brunei is important in influencing the number of shoppers. The outcome of our research is consistent with the results of Rizzo et al. (2014) which reported that the peak times recorded are during school holidays and festive seasons. Moreover, Bruneians have family-oriented culture, so they are likely to go to Miri during holiday to spend time with their family.

Lastly, the coefficient of bonus effect is 22.6 percent. This means that the number of people travelling to Miri is 22.6 percent higher in the first 20 days after bonus then in the remaining days of the month. This result is also statistically significant with a p-value of 0.0000. Bonus has similar effect with payday as it increases purchasing power of Bruneians. Every year December to early January, the number of Bruneian shoppers to Miri increases almost double after receiving their bonus.

Several robustness checks have been done to confirm the reliability of the regression results. This includes multicollinearity and heteroscedasticity tests. One of the assumptions of the classical linear regression model is that there is no exact linear relationship among the regressors. If there are one or more exact linear relationships among the regressors then multicolinearity exists in the model. The partial correlations between the independent variables have been checked in STATA. We find no exact linear relationship or any strong linear relationships between the independent variables.

The classical linear regression model also assumes that the error term $u_{i}$ in the regression model has homoscedasticity (equal variance) across observations. If the assumption of homoscedasticity is not satisfied, we have the problem of heteroscedasticity (unequal variance) in the model. To test for heteroscedasticity, we have used the Breusch-Pagan test by obtaining the squared residuals (denote as uhatSq) as a proxy for true squared error term, to see if the uhatSq are related to one or more independent variables in the model. The null hypothesis is that the error variance is homoscedasticity. The F-test shows the p-value is 0.4202 which is at a 5 percent significance level we accept the null hypothesis of error variance is equal to zero if the p-value is more than 0.05 . The results shown in Table 2 indicate that heteroscedasticity is not present in the results. 
Table 2

Breusch-Pagan Test for Heteroskedasticity

\begin{tabular}{lcccccc}
\hline uhat Sq & Coef. & Std. Err & $\mathrm{t}$ & $\mathrm{P}>|\mathrm{t}|$ & \multicolumn{2}{c}{ [95\% Conf. Interval] } \\
\hline ln Exchange Rate & -0.631 & 0.519 & -1.22 & 0.224 & -1.649 & 0.387 \\
Payday & 0.098 & 0.074 & 1.34 & 0.182 & -0.046 & 0.243 \\
Sales & 0.107 & 0.076 & 1.39 & 0.165 & -0.044 & 0.256 \\
Holiday & 0.001 & 0.075 & 0.02 & 0.988 & -0.146 & 0.148 \\
Bonus & -0.070 & 0.161 & -0.43 & 0.665 & -0.385 & 0.246 \\
_cons & 0.717 & 0.534 & 1.34 & 0.180 & -0.331 & 1.766 \\
\hline
\end{tabular}

The AOV table

\begin{tabular}{llll}
\hline Source & SS & df & MS \\
\hline Model & 7.239 & 5 & 1.448 \\
Residual & $1,587.831$ & 1,090 & 1.457 \\
Total & $1,595.070$ & 1,095 & 1.457 \\
\hline
\end{tabular}

Number of obs $=1,096$

$\mathrm{F}(5,1090)=0.99$

Prob > F $=0.420$

$\mathrm{R}$-squared $=0.005$

Adj R-squared $=-0.0000$

Root MSE $=1.207$

Note: $|\mathrm{t}|$ means the absolute $\mathrm{t}$ value because $\mathrm{t}$ can be positive or negative.

$\mathrm{AOV}=$ Analysis of Variance.

Furthermore, robust standard error has also been done and the results are in Table 3. By comparing the results with the earlier regression, there are no changes in the coefficients and no bigger changes in the standard errors and $t$-values detected which confirms no presence of heteroscedasticity in the model. Thus, the assumption of no multicollinearity and homoscedasticity are satisfied. 


\section{Table 3}

Robust Standard Error

Linear regression

\begin{tabular}{lcccccc}
\hline In Brunei Shoppers & Coef. & Robust Std. Err & $\mathrm{t}$ & $\mathrm{P}>|\mathrm{t}|$ & \multicolumn{2}{c}{$[95 \%$ Conf. Interval] } \\
\hline ln Exchange Rate & 2.098 & 0.194 & 10.81 & 0.000 & 1.717 & 2.478 \\
Payday & 0.119 & 0.024 & 4.87 & 0.000 & 0.071 & 0.167 \\
Sales & 0.008 & 0.027 & 0.32 & 0.750 & -0.044 & 0.061 \\
Holiday & 0.709 & 0.024 & 29.18 & 0.000 & 0.662 & 0.757 \\
Bonus & 0.226 & 0.049 & 4.59 & 0.000 & 0.130 & 0.323 \\
_cons & 5.237 & 0.193 & 27.08 & 0.000 & 4.858 & 5.617 \\
\hline
\end{tabular}

Number of obs $=1,096$

$\mathrm{F}(5,1090)=319.59$

Prob $>$ F $=0.0000$

R-squared $=0.505$

Root MSE $=0.396$

\section{Impact of cross-border shopping on Brunei economy}

To meet the second objective (i.e. to measure the outflow of expenditure from Brunei due to cross-border shopping in Miri), a survey was conducted on cross border shoppers at Sungai Tujoh Immigration Control post upon receiving permission from higher authority. The survey questionnaire was also randomly distributed in some other places. A total of 100 cross-border shoppers responded to this survey. The survey was conducted using a specially designed questionnaire to find out the amount of money spent by an individual in Miri and types of goods and services purchased.

Findings of our survey are presented in Table 4. Most of the respondents, 96 percent were Bruneians, and 4 percent were permanent residents. This table also shows the distribution of monthly per capita income of the respondents. Majority of the respondents (58 percent) has indicted having a monthly personal income less than $\mathrm{B} \$ 500$, while 24 percent of the respondents showed having a monthly income between $\mathrm{B} \$ 501$ and $\mathrm{B} \$ 1900$. These figures indicate that low income Bruneians are spending their income in Miri because they can buy more necessities, as suggested in Rizzo et al. (2014). 


\section{Table 4}

Amount of money spent and types of goods \& services purchased

\begin{tabular}{|c|c|c|c|}
\hline Item & $\%$ of total & Item & $\%$ of total \\
\hline Residency groups $(n=100)$ & & Average spending per person $(n=88)$ & \\
\hline Brunei citizens & 96 & Up to $B \$ 100$ & 38 \\
\hline Permanent residents & 4 & $\mathrm{~B} \$ 101$ to 300 & 43 \\
\hline \multirow[t]{2}{*}{ Temporary residents } & 0 & $\mathrm{~B} \$ 301$ to 500 & 13 \\
\hline & & $\mathrm{B} \$ 501$ or above & 7 \\
\hline Monthly personal income $(n=90)$ & & Major product purchased $(n=91)$ & \\
\hline Up to $B \$ 500$ & 58 & Food \& Beverages & 78.0 \\
\hline $\mathrm{B} \$ 501$ to 1900 & 24 & Clothes & 76.9 \\
\hline $\mathrm{B} \$ 1901$ to 2500 & 7 & Shoes \& Handbags & 48.4 \\
\hline $\mathrm{B} \$ 2501$ to 3500 & 7 & Books & 42.9 \\
\hline $\mathrm{B} \$ 3501$ to 4500 & 2 & Household items & 48.4 \\
\hline $\mathrm{B} \$ 4501$ or above & 2 & Other goods & 31.9 \\
\hline Purpose of visit $(n=91)$ & & Services purchased $(n=73)$ & \\
\hline Shopping & 90.1 & Beauty or hair salon & 21.9 \\
\hline Leisure or Entertainment & 52.7 & Bill payments & 26.0 \\
\hline Visiting relatives or friends & 19.8 & Vehicle servicing & 15.1 \\
\hline Work or business & 5.5 & Entertainment outlets & 52.1 \\
\hline \multirow[t]{2}{*}{ Other } & 7.7 & Dental services & 5.5 \\
\hline & & Other services & 32.9 \\
\hline
\end{tabular}

Note: Socioeconomic characteristics of the respondents (gender, age, marital status, and occupation) were also collected during the survey, but not shown here.

Purposes of visit to Miri by the participants are also shown in Table 4. 90.1 percent of the respondents went for shopping and a considerable proportion had other reasons for crossing the border (beside or in addition to shopping): about 52.7 percent went for leisure and entertainment and 19.8 percent to visit relatives and friends. The most popular items purchased in Miri were food and beverages (78 percent), clothing (76.9 percent), shoes and hand bags (48.4 percent). Spending on services was mainly for entertainment outlets (52.1 percent), beauty or hair salons (21.9 percent), and vehicle servicing (15.1 percent).

One of the reasons why Bruneians spend largely on food and beverages is due to cheaper prices. Since, most of these respondents are day-trippers they tend to dine out after the long journey. This finding is in line with Subramaniam et al. (2013) who found that most of the day trippers spend mainly on food and beverages.

The average amount spent in Miri per person was $\mathrm{B} \$ 155$. Some variation can be observed across income categories. Majority of the respondents (43 percent) spent on average $\mathrm{B} \$ 101$ to 
\$300 for each trip to Miri. This was followed by a total of 38 percent of respondents who spent less than $\mathrm{B} \$ 100$, and 13 percent of respondents spent $\mathrm{B} \$ 301$ to 500 (Table 4 ). However, it should be noted that most of the respondents were between 18-24 years old and most of them were females. Majority of them were single and were still studying, thus income of a large number of respondents falls below B $\$ 500$ (from survey responses, not shown in Table 4)

Concerning the statistics on the number of people crossing the border at Sungai Tujoh we can see that in 2016, a total of 1,129,050 people had crossed the border at Sungai Tujoh. Therefore using data from the survey (B $\$ 155$ per person), we can estimate a total yearly expenditure of $\mathrm{B} \$ 175$ million. This figure is about 1.11 percent of gross domestic product (GDP) of Brunei in 2016 (B $\$ 15,747.7$ million).

The survey also asked the participants to state their knowledge of exchange rate of Malaysia-Brunei exchange rate (Table 5). About 95 percent of the respondents have knowledge of exchange rate. Most of the respondents agreed that it is good for the consumer when Malaysian ringgit is depreciating as they can purchase more goods at lower prices. In terms of the Brunei economy, 60 percent of the respondents disagreed that Malaysian ringgit depreciation is good as most of their responses stated that it could lead to money leakage to Miri. This result shows that some of the respondents are not aware on how depreciation can affect Brunei economy. To make it worse, 69 percent of them tend to spend more money when Malaysian ringgit depreciates which can weaken the domestic economy.

\section{Table 5}

Exchange Rate Knowledge of Respondents

\begin{tabular}{lc}
\hline Items & \% of total \\
\hline Understanding of exchange rate $(n=97)$ & 94.8 \\
Yes & 5.2 \\
No & \\
\hline Malaysian ringgit depreciation is good for customer $(n=93)$ & 95.7 \\
Yes & 3.2 \\
No & 1.1 \\
Neutral & 24.7 \\
\hline Malaysian ringgit depreciation is good for Brunei economy $(n=89)$ & 59.6 \\
Yes & 15.7 \\
No & \\
Neutral & \\
\hline Spend more money when the exchange of Brunei dollars to & 69.1 \\
Malaysian ringgit is increasing (n=97) & 30.9 \\
Yes & \\
No &
\end{tabular}




\begin{tabular}{ll}
\hline Frequency of checking exchange rate $(n=97)$ & \\
Daily & 8.2 \\
Weekly & 8.2 \\
Monthly & 11.3 \\
Upon visit/trip & 72.2 \\
\hline Get updated with the figures of exchange rate $(n=97)$ & \\
Money changer & 59.8 \\
Family & 67.0 \\
Friends & 62.9 \\
Internet & 48.5 \\
Bank & 9.3 \\
\hline
\end{tabular}

\section{Conclusion}

Using a regression analysis, this paper has shown the relationship between BruneiMalaysia's exchange rate and the number of cross-border trips made by residents of Brunei to Miri, a border town of East Malaysia. To our knowledge this is the first study to estimate the effects of exchange rate fluctuations on cross-border shopping of Bruneians.

A key finding of this work is that border crossing of Bruneians is heavily influenced by exchange rate fluctuations. The empirical evidence provided suggests that in response to a depreciation of Malaysian ringgit (an appreciation of Brunei dollar), more Bruneian shoppers decide to cross the border to shop in Miri, motivated by lower price of goods there. Generally, Brunei cherishes a family-oriented culture and this has led to an increase in the cross-border movement as they tend to go abroad to spend their time together.

Other factors that are found statistically significant in motivating the decision of Brunei shoppers to shop across border are payday, holiday, and bonus period in Brunei. In contrast, sales promotion in Miri is not statistically significant in influencing the number of Bruneian shoppers, thus rejecting our assumption that it will attract more Bruneian. This might be due to the fact that people are not aware of these promotions.

Earlier studies on cross-border shopping of Bruneians did not emphasize the importance of exchange rate as a motivating factor to shop across the border. One reason for this may be that at the time of their studies exchange rate of Malaysian ringgit per Brunei Dollar did not fluctuate as much as it is now.

Another important finding of this study is that most respondents go to Miri for shopping; i.e to spend ( 90 percent of the respondents). This affects local businesses of Brunei in terms of reduced sales revenue. Therefore, Brunei needs to improve the competitiveness of its retail sector particularly in terms of price and variety. The country may start exploring ways 
to offer goods and services at prices compared to those offered by competitors across the border.

Based on our survey responses, we have calculated the estimated average spending per person in Miri to be $\mathrm{B} \$ 155$ and total expenditure amount of Bruneians in Miri to be at B $\$ 175$ million in 2016. This figure accounted for 1.11 percent of gross domestic product (GDP) of Brunei in 2016. This total amount of expenditure is an outflow of money and is a leakage from the local economy of Brunei. However, this result is to be used with caution as the calculation is based on the survey responses of only 100 respondents.

Bruneians also go cross-border to other East Malaysian towns of Limbang, Labuan and Kota Kinabalu. If we calculate the spending of Bruneian shoppers in all these border towns, the total expenditure amount would certainly increase. This may led to an even higher outflow of money and deteriorate the domestic economy of Brunei as Bruneians prefer to spend abroad than locally. This has raised a policy concern at government level as to how to reduce the rate of such visits and spending. Consequently, the Centre for Strategic and Policy Studies of Brunei has come up with a better plan to make Brunei the preferred holiday destination for all by 2025. They are developing competitive strategies to motivate cross border shoppers to shop locally

\section{References}

Authoriti Monetari Brunei Darussalam. (2017). AMBD Statistical Bulletin Q4 2017. Retrieved from http://www.ambd.gov.bn/Pages/Monthly-Statistical-Bulletin

Bello, P. (2017). Exchange rate fluctuations and border crossings: Evidence from the SwissItalian border. IdEP Economic Papers, 1701.

BP. (2017). BP statistical review of world energy June 2017. Retrieved from https://www.bp.com/content/dam/bp/en/corporate/pdf/energy-economics/ statistical-review-2017/bp-statistical-review-of-world-energy-2017-full-report.pdf

Exchange Rate UK. (2017-2018). Brunei Dollar (BND) to Malaysia Ringgit (MYR) exchange rate history. Retrieved March 12, 2017 from https:/ / www.exchangerates.org.uk/ BND-MYRexchange-rate-history.html

Brunei Government. (2017). Brunei Darussalam statistical yearbook 2016. Bandar Seri Begawan, Brunei: Department of Statistics, Department of Economic Planning and Development, Prime Minister's Office.

Chandra, A., Head, K., \& Tappata, M. (2014). The economics of border travel. Review of Economics and Statistics, 96(4), 648-661.

Cheong, D., \& Rahman, K. (2015). White paper on making Brunei Darussalam the preferred holiday destination for all by 2025. CSPS Report, September. Brunei Darussalam, Brunei: Centre for Strategic and Policy Studies. 
Espland, M., Friberg, R., \& Wilander, F. (2005). Demand and distance-evidence on cross-border shopping. SSE? EFI Working paper Series in Economics and Finance No. 587, Sweden: Stockholm School of Economics.

European Commission. (2004). Qualitative study on cross-border shopping in 28 European countries. Retrieved from http://ec.europa.eu/consumers/topics/crossborder_shopping_en.pdf

Gelbman, A., \& Timothy, D. J. (2010). Border complexity, tourism and international enclaves: A case study. Annals of Tourism Research, 38(1), 110-131.

IMF. (2018). World economic outlook database. April 2018, International Monetary Fund.

Lau, H., Sin, L. Y., \& Chan K. K. (2005). Chinese cross-border shopping: An empirical study. Journal of Hospitality $\mathcal{E}$ Tourism Research, 29(1), 110-133.

Neilsen, S. B. (2002). Cross-border shopping from small to large countries. Economic Letters, 77(3), 309-313.

Oxford Business Group. (2016). The Report: Brunei Darussalam 2016.

Piron, F. (2002). International outshopping and ethnocentrism. European Journal of Marketing, $36(1-2), 189-210$.

Rizzo, G., Cheong, D., \& Abdullah, Y. (2014). Cross-border expenditure of Bruneians in Miri, Sarawak. CSPS Policy Brief, Issue 3.

Rizzo, G., \& Hau, L. C. (2015). Promoting Brunei Darussalam as a holiday destination: A survey of local and overseas tourists' preferences. CSPS Working Paper-Series 003.

Soloman, M. (2012). Consumer behavior: Buying, having and being. Upper Saddle River. New Jersey, Prentice Hall.

Subramaniam, T., Devadason, E. S., \& Sundararaja, S. (2013). Cross-border shopping: Examining motivations from the perspective of Bruneian visitors in Limbang, Malaysia. Jurnal Ekonomi Malaysia, 47(1), 21-30.

Tak, K. H., \& Wan, D. (2008). The cross-border shoppers' behavior: The case of Singapore. International Journal of Data Analysis and Strategies, 1(1), 104-115.

Timothy, D. J. (2005). Shopping tourism, retailing and leisure. Clevedon, North Somerset, UK: Channel View.

Lee, S. C. W. (2018). Cross-border tourism between Brunei and Eastern Malaysia. Paper presented at International Tourism Conference \& Exhibition: Tourism and Heritage: The ASEAN \& Borneo Context, January 16-17, 2018, Universiti Brunei Darussalam. 